\title{
Predictive model to determine the compatibility of lignocellulosic fibers with cement
}

The chemical and physical compatibility of lignocellulosic fibers with the cement matrix plays a fundamental role in determining the properties of the composite such as durability and mechanical strength. The compatibility models, which have been developed up to now, provide information after the fiber has been mixed with the binder by constructing the composite hydration curve of temperature vs. tempo. There is still no predictive method of measuring compatibility, that permit to verify the influence of the physical and chemical characteristics of the lignocellulosic fibers on the behavior of greater or lesser compatibility with the cement. Therefore, the aim of the work was to develop a predictive model of compatibility (CPC) between lignocellulosic fibers and cement that does not need to do the hydration curve of the mixtures. The proposed CPC compatibility model takes into account the physical variables; specific mass and degree of swelling and chemical variables; content of total soluble solids, sugars and tannins in lignocellulosic fibers previously obtained. This information provides an alternative measure of compatibility comparable to the calculation model (CX), with the same degree of reliability and validity. Additionally, easier to obtain and achievable in a simpler laboratory.

Keywords: Compatibility calculation; Fiber-cement; Hydration reaction; Lignocellulosic waste; Physical properties; Chemical properties.

\section{Método 'a priori' para avaliar a compatibilidade de fibras vegetais com cimento}

\begin{abstract}
A compatibilidade química e física das fibras vegetais com a matriz cimentícia possui um papel fundamental na determinação das propriedades do compósito, tais como durabilidade e resistência mecânica. Os modelos de cálculo que medem a compatibilidade, até aqui desenvolvidos, fornecem informações após a mistura da fibra com o aglomerante, através da construção da curva de hidratação do compósito (temperatura x tempo). Ainda não existe um método de medida da compatibilidade 'a priori', ou seja, que verifique a influência das características físicas e químicas das fibras vegetais no comportamento de maior ou menor compatibilidade com o cimento. Diante disso, o objetivo do trabalho foi desenvolver um modelo preditivo de compatibilidade (CFQ) entre fibras vegetais e cimento que não necessite da realização da curva de hidratação das misturas. O modelo de compatibilidade proposto CFQ leva em consideração variáveis de caracterização físicas (massa específica e grau de inchamento) e químicas (sólidos solúveis totais, teor de açucares e teor de taninos) das fibras vegetais obtidas previamente, fornecendo uma alternativa de medição da compatibilidade comparável ao modelo de cálculo da literatura CX, com o mesmo grau de confiabilidade e validade, de fácil obtenção e realizável em um laboratório mais simples.
\end{abstract}

Palavras-chave: Cálculo de compatibilidade; Fibra-cimento; Reação de hidratação; Aproveitamento de resíduos; Propriedades físicas; Propriedades químicas.

Topic: Desenvolvimento, Sustentabilidade e Meio Ambiente

Reviewed anonymously in the process of blind peer.
Received: $10 / 08 / 2019$

Approved: 28/09/2019
Maria Lidiane Marques (ii)

Instituto Federal de Ciência e Tecnologia da Bahia, Brasil http://lattes.cnpq.br/0896370936952827

http://orcid.org/0000-0001-6837-3389

lidiane marques@yahoo.com.br

Fermin de la Caridad Garcia Velasco (iD)

Universidade Estadual de Santa Cruz, Brasil

http://lattes.cnpq.br/2300280094545118

http://orcid.org/0000-0003-0803-9148

fermingv@gmail.com

Francisco Heriberto Martínez Luzardo (D) Universidade Estadual de Santa Cruz, Brasil http://lattes.cnpq.br/43333332503448953 http://orcid.org/0000-0003-1706-8231 fhmluzardo@uesc.br

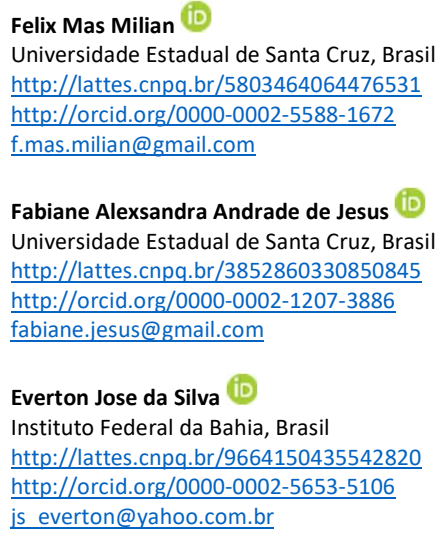

Referencing this:

MARQUES, M. L.; VELASCO, F. C. G.; LUZARDO, F. H. M.; MILIAN, F. M.; JESUS, F. A. A.; SILVA, E. J.. Predictive model to determine the compatibility of lignocellulosic fibers with cement. Revista Ibero Americana de Ciências Ambientais, v.10, n.5, p.270-286, 2019. DOI: http://doi.org/10.6008/CBPC2179-6858.2019.005.0024 


\section{INTRODUCTION}

The interest in the subject of compatibility of lignocellulosic materials in cementitious matrixes arosed in the decade of the 60s when the first works were published in the area. The pioneers were Sanderman et al. (1964) and Weatherwax et al. (1964). From then on, several researchers began to study the subject and to focus on understanding the mechanisms of interaction between lignocellulosic fibers and the cement matrix.

The first consideration known in the literature is that the presence of the lignocellulosic fiber increases the cement setting time. The hydration curves of the time vs. temperature of mixtures made with lignocellulosic fibers and cement are widely used to study and evaluate the compatibility. This motivated the elaboration of calculation models to determine this property (HOFSTRAND et al., 1984; HACHMI et al., 1990; KAREDE et al., 2003; HERRERA et al., 2008; PASCA et al., 2010; FAN et al., 2012; OLORUNNISOLA, 2008).

The hydration curve of the composites made with lignocellulosic fibers and cement is generally determined by the calorimetry technique with coupled $\mathrm{K}$ type thermocouple sensors. In more recent studies by Lima et al. (2015) they used Bragg fiber optic sensors to make the hydration curves. The second important consideration is that in some cases pretreatment of these wastes (washing with cold water, hot water, $\mathrm{NaOH}$, $\mathrm{Na2SO}$ ) or the use of chemical accelerators $\left(\mathrm{CaCl}_{2}\right)$ to increase their compatibility (ALBERTO et al., 2000; CALADO et al., 2000; RAMOS, 2003; ASASUTJARIT et al., 2007; OLORUNNISOLA, 2008; RAMADEVI et al., 2012; FERRAZ et al., 2012).

In the last decade, some literature review work on wood-cement or fiber-cement compatibility has been published (JORGE et al., 2004; PACHECO-TORGAL et al., 2011; BIN et al., 2014). These studies aimed to investigate the use of plant fibers in cement matrixes, including: characteristics of the fibers, properties and description of treatments that improve their performance; compatibility between the fibers and the cement matrix and how these fibers influence the cement hydration. Also, durability and performance of the composites, as well as to suggest future trends for this theme.

Several researchers have studied different methods of compatibility evaluation based on different approaches and mathematical formulations, taking account the greatest hydration temperature (SANDERMANN et al., 1964), greatest time to reach maximum temperature of hydration (WEATHERWAX et al., 1964), greatest temperature of hydration and ambient temperature (VILELA et al., 1968) and the greatest temperature of hydration and the derivative of the temporal function of temperature (HOFSTRAND et al., 1984).

Others models of calculation took into consideration, besides the previous parameters evaluated by the authors (time and maximum temperature), as the quantities and thermal system parameters (amount of wood, specific heat of composite constituents, the total energy of hydration reaction of mixture, maximum rate of heat and the total heat released within a time interval) (HACHMI et al., 1990; KARED, 2010; ASASUTJARIT et al., 2007; FERRAZ et al., 2012; VILELA et al., 1968; HERRERA et al., 2008; PASCA et al., 2010; KAREDE et al., 2003). A compatibility evaluation scheme using the time of the cement setting process (TR), 
which is the ratio between the initial time of the hydration process of wood-cement mixing with the fresh cement was proposed (OLORUNNISOLA, 2008). An approach taking into consideration the areas under the hydration curve of wood-cement mixtures with pure cement was reported (HACHMI et al., 1990; FAN et al. 2012). However, there are still no standardized methods to measure the temperature of hydration woodconcrete mixtures, and the complexity of binder hydration process may hamper the interpretation of results (KAREDE et al., 2003).

What still motivates the interest of this theme by researchers is that a large amount of lignocellulosic waste is generated worldwide from various sources, such as agriculture, construction, wood processing, furniture manufacturing and urban pruning. Which leads to environmental concerns about the disposal of such waste. The use of these materials in cementitious composites is a good alternative. However, there are some restrictions, of the physico-chemical compatibility of these wastes with cement. The methods of compatibility calculations developed to date consider the effects of the incorporation of fibers in the cementitious mass after mixing, on several parameters such as: temperature, time, heat and heat rate, among others. There is not yet a mathematical model to calculate the compatibility of the predictive form using physical and chemical characteristics of the lignocellulosic fibers.

From the above, the aim of the work was to develop a predictive calculation model to determine the compatibility of lignocellulosic fibers with cement considering the physical and chemical characteristics of lignocellulosic fibers for its application in cementitious composites. The purpose of the developed compatibility model $\left(\mathrm{C}_{\mathrm{PQ}}\right)$ is to offer an alternative measurement of plant fiber-cement compatibility comparable to the CX calculation model (PASCA et al., 2010), ie with the same degree of reliability and validity. Also, it does not need temperature and heat hydration measurements of the mixture, which is easily obtainable and achievable in a simpler laboratory, taking into account only some physical and chemical properties of the fibers.

\section{MATERIALS AND METHODS}

The developed calculation methods reported consider the effects of incorporating the fiber into the cement mixture, ie, the interference of the presence of fiber in the cement mass after mixing, such as: temperature, time, and heat rate, among others. Therefore, the proposed method (CPQ), which measures the compatibility through physical and chemical parameters of plant fibers prior to cement mixing, may be a simple, fast and reliable way to pre-select these materials with potential for use in cementitious matrices.

The choice of the variables that made up the compatibility model was based on information on the physical and microstructural characterization of lignocellulosic materials, which provided important information on the characteristics of the fibers studied, such as total soluble solids content (SST), sugar content (TA). ) and tannin content (TT), variables influencing the compatibility of fiber-cement composites. The correlation between the physical properties of fibers and their compatibility measured by different calculation models was evaluated by the authors and it was concluded that the main variables that influence the response of greater or lesser compatibility of fiber-cement mixtures are: specific mass and degree of fiber 
swelling (MARQUES et al., 2016).

The authors conducted extensive research on all calculation models already in the literature, which allowed us to find the existing mathematical formula of compatibility that best represented the behavior of the fiber-cement mixture. As a result of this study, the CX index (PASCA et al., 2010), was the calculation model that most realistically reflected this connection by considering not only the greatest heat generated in the hydration process, but all the heat generated during such a process.

Given the study and analysis of these physical and chemical variables, four adjustments of in nature fiber compatibility models (without washing treatment) with Portland cement were obtained. The first considering only the chemical variables, the second considering only the physical variables, the third considering all the physical and chemical variables, and lastly, a simplified model that takes into consideration the physical and chemical variables obtained through simpler methodologies, achievable in laboratories with little technical equipment.

The studied fibers were: coconut (Cocos nucifera L.), eucalyptus bark (Eucalyptus grandis), baroness leaves (Eichhornia crassipes) and cocoa bark (Theobroma cacao). The fiber samples were collected at different locations in the southern Bahia region. Coconut fiber was obtained from the industrial waste from the coconut water processing in the company Plancomar Companhia Agrícola LTDA, in the city of Una, Bahia (BA/Brazil). The residual eucalyptus bark at the company VERACEL pulp and paper producer, in the city of Eunápolis/BA(Brazil). Cocoa bark, in the areas of the Executive Committee of the Cocoa Plan (CEPLAC), in the municipality of Ilhéus/BA(Brazil). Finally, the Baroness was collected directly on the Cachoeira River, in Salobrinho neighborhood, in Ilhéus/BA. The fibers were dried in the oven for 2 hours at a temperature of 100 $\pm 2{ }^{\circ} \mathrm{C}$ and then milled in the Willye-type windmill and sieved to size $\leq 2.0 \mathrm{~mm}$.

\section{Composites Preparation}

To obtain the CX compatibility index of all the blends studied, fiber-cement composites were prepared. In this work was used the cement Portland CPV - ARI, in a Blaine superficial area of $4.397 \mathrm{~cm}^{2} / \mathrm{g}$ and specific mass of $3.09 \mathrm{~g} / \mathrm{cm}^{3}$. The water/cement ratio $(\mathrm{A} / \mathrm{C})$ was set at 0.4 for maintaining an adequate amount of water, able to hydrate all the cement grains without impairing the workability of the mix when added the vegetable fibers. A Cement chemical analysis is shown in table 1 . The proportion of fiber was $5 \%$ about to the cement mass to make sure hydration conditions with the $A / C$ fixed ratio (BILBA et al., 2003).

Table 1: Chemical composition of the cement, wt (\%).

\begin{tabular}{|l|l|l|l|l|l|l|l|l|l|l|l|l|}
\hline Oxides materials & $\mathbf{N a}_{2} \mathbf{O}$ & $\mathbf{M g O}$ & $\mathbf{A l}_{2} \mathbf{O}_{\mathbf{3}}$ & $\mathbf{S i O}_{2}$ & $\mathbf{P}_{2} \mathbf{O}_{5}$ & $\mathbf{S O}_{3}$ & $\mathbf{K}_{\mathbf{2}} \mathbf{O}$ & $\mathbf{C a O}$ & $\mathbf{T i O}_{2}$ & $\mathbf{M n O}$ & $\mathbf{F e}_{2} \mathbf{O}_{3}$ & $\mathbf{S r O}$ \\
\hline CPV-ARI & 0,620 & 2,96 & 3,90 & 15,9 & 0,130 & 4,06 & 0,760 & 67,7 & 0,330 & 0,110 & 3,20 & 0,220 \\
\hline
\end{tabular}

\section{Physical-Chemical Characterization}

For determination of the specific mass $(\mathrm{SM}) 0.5 \mathrm{~g}$ of fiber was placed in a beaker of $(10 \pm 0.1) \mathrm{mL}$, then $5 \mathrm{~mL}$ of distilled water was added and the displaced volume $\left(V_{d}\right)$. The specific mass was calculated by dividing the dry fiber mass by the volume of water displaced by the sample, expressed in $\mathrm{g} . \mathrm{cm}^{-3}$. 


$$
S M=\frac{w_{f d}}{V_{d}}
$$

At where: $w_{f d}$ - fiber dry weight $(\mathrm{g})$; $V_{d}$ - dislocated volume $\left(\mathrm{cm}^{3}\right)$

The degree of swelling test (DS) was performed by weighing $0.5 \mathrm{~g}$ of fiber and placing it in a beaker of $(10 \pm 0.1) \mathrm{mL}$, then $5 \mathrm{~mL}$ of distilled water was added and allowed to stand for 24 hours. After this time, the fiber was filtered and air dried on filter paper. The filter paper was weighed with the wet fiber mass and the difference between the wet fiber filter paper and the filter paper was calculated, thereby obtaining the wet fiber mass $\left(f_{w}\right)$. Calculation of the absorbed water $\left(A_{w}\right)$ was performed according to Eq. (2). The degree of swelling was obtained by the ratio of the absorbed water mass to the dry fiber mass Eq. (3).

$$
\begin{aligned}
A_{w} & =f_{w}-w_{f d} \\
D S & =\frac{A_{w}}{w_{f d}}
\end{aligned}
$$

At where: $f_{w}$ - mass of the wet fiber $(\mathrm{g})$; $w_{f d}$ - fiber dry weight $(\mathrm{g})$; $A_{w}$ - absorbed water (g).

The determination of the Total Soluble Solids (TSS) was carried out by taking aliquot of $10 \mathrm{~mL}$ of the aqueous extract of the fibers in $50 \mathrm{~mL}$ beaker, placed in an oven at a temperature of $(103 \pm 2)^{\circ} \mathrm{C}$ and dried to a constant weight. The determination was performed in triplicate according to Eq. (4).

$$
\operatorname{TSS}\left(\mathrm{mg} \mathrm{L}^{-1}\right)=\frac{\mathrm{B}_{\mathrm{s}}-\mathrm{B}_{e}}{0.005}
$$

At where: $B_{S}$ Mass of the sample beaker (g); $B_{e}$ Mass of the empty beaker (g).

The solid / liquid extraction of tannins, sugars and total dissolved solids from the samples was performed in aqueous medium. $5.00 \mathrm{~g}$ of the dried and ground fibers were weighed and placed into $100 \mathrm{~mL}$ beakers for each fiber containing $35 \mathrm{~mL}$ of distilled water. The beakers were capped with foil and placed in a water bath for $30 \mathrm{~min}$ at $90^{\circ} \mathrm{C}$. After completion of the maceration process, the floating solution was decanted and filtered in a $500 \mathrm{~mL}$ flask. This operation was repeated 5 times per sample and the obtained extract was filtered in the same $500 \mathrm{~mL}$ flask. Subsequently, the volume was filled with distilled water until the $500 \mathrm{~mL}$ of the flask was filled. The washed residue retained on the filter was taken to the oven for drying at $(103 \pm 2)^{\circ} \mathrm{C}$, then stored for further studies.

The extract contained in the $500 \mathrm{~mL}$ flask was filtered on filter paper to determine the soluble sugars concentrtion (SS) with a spectrophotometer (Spectroquant TR 420) at wavelength of $520 \mathrm{~nm}$ to get the calibration curve of glucose, where it was varied at concentration in the range of 0 to $100 \mathrm{mg} \mathrm{L}^{-1}$ with a correlation coefficient of 0.999 . Eq. (5) corresponds to the result of the sugar concentration in mg. $\mathrm{L}^{-1}(\mathrm{Cs})$.

$$
\mathrm{C}_{\mathrm{s}}\left(\mathrm{mg} \mathrm{L}^{-1}\right)=\frac{(\mathrm{A}+0.0045)}{0.0087}
$$

At where: A Absorbance according to the calibration curve obtained.

The determination of the tannin content (TC) was performed by direct measurement under UV light with a spectrophotometer Spectroquant TR 420. Tannic acid solutions were prepared $88 \%$ and Gallic acid PA 
(Biotec) and commercial mimosa tannin (Tanac SA) at concentrations $0,1 \mathrm{mg} \mathrm{L}^{-1}$. The absorption spectrum of each extract in the reported wavelength range was determined and a calibration curve was developed for each at the maximum absorption wavelength. To determine the concentration of tannins, the extracts were considered to have maximum absorbance at the wavelength of $260 \mathrm{~nm}$ for the Baronesa and $280 \mathrm{~nm}$ for the other lignocelullosic fibers. The calibration curve of gallic acid PA (Biotec) corresponding to $260 \mathrm{~nm}$ was used according to Eq. (6) (Cti $)$ and tannic acid $88 \%$ pm at $280 \mathrm{~nm}$ according to Eq. (7) (Ctii).

$$
\begin{aligned}
& \mathrm{Ct}_{\mathrm{i}}\left(\mathrm{mg} \mathrm{L}^{-1}\right)=\frac{(\mathrm{A}-0.007)}{0.449} \\
& \mathrm{Ct}_{\mathrm{ii}}\left(\mathrm{mg} \mathrm{L}^{-1}\right)=\frac{(\mathrm{A}+0.013)}{0.106}
\end{aligned}
$$

\section{Physicochemical Model ( $\left.C_{P C}\right)$}

The tests of compatibility between the lignocelullosic fibers and the cement are generally difficult to do and complex, which demands the implementation of a simpler and quicker method to measure the potentiality of applying a certain lignocelullosic material in cementitious matrices. In view of this need, the $\mathrm{C}_{\mathrm{PC}}$ is characterized as predictive model of compatibility because it does not need to perform the hydration curve of the mixtures, which are measured after, that is, by measuring the thermal behavior of the composite after the introduction of the fiber.

The proposed compatibility model $C_{P C}$ took into account variables of physical and chemical characterization of previously obtained lignocelullosic fibers, such as: specific mass, degree of swelling, sugar content, tannin content and total soluble solids. The Statgraphics Plus program was used to adjust, through multiple linear regression analysis, a model that is related to the compatibility model already proposed in the literature, the CX model (PASCA et al., 2010). In order to carry out the internal validation of the proposed model, was used through the Student's t-test in the four studied lignocelullosic fibers, baronesa, cocoa, coconut and eucalyptus, and in three other fibers (banana peel, of banana and piaçava) all without washing. Student's t-test was applied to verify if the proposed compatibility model is comparable to the value obtained by the CX literature compatibility calculation method.

\section{RESULTS AND DISCUSSION}

\section{Variables of the $\mathrm{C}_{\mathrm{pc}}$ Model}

The compatibility calculation models developed so far provide information on bonding between lignocellulosic fibers and Portland cement after mixing these materials by constructing the hydration curve of temperature vs time. With this information and using some variables such as the mass of the constituents, specific heat of the materials and thermal properties of the calorimeter used, it is possible, to reach a value of compatibility between the fiber and the cement through some calculations. After analyzing the already existing calculation models (BIN et al., 2014), it was possible to check the compatibility model that best represents the behavior of the fiber cement mixture. As a result of this study, the CX index was the calculation model that more realistically reflected the fiber-cement affinity considering not only the greatest heat 
generated in the hydration process, but also all the heat generated. The aim of the Compatibility Model ( $\left.C_{P C}\right)$ was to offer an alternative measurement of the compatibility between lignocellulosic fibers and cement that is comparable to the CX calculation model, with the same degree of reliability and validity, and that does not need the measurements of temperature and the heat of hydration of the mixture. At the same time a model which is easy to get and achievable in a simpler laboratory, taking into account only the physical and chemical properties of the lignocellulosic fibers.

The choice of the variables that made up the compatibility model emerged from the study of the physical and microstructural characterization of the materials that provided important information about the characteristics of the studied fibers, being the total soluble solids, sugars, and tannins contents, the most influential variables in the compatibility of fiber-cement composites. For Pomarico (2013) the main cause of the inhibition of cement in the presence of lignocellulosic fibers is the simple sugars, which migrate to the surface of the fiber forming an inhibitory layer, reducing the speed of the hydration reaction. Compounds such as terpenes, resins, and fats, reduce the strength of the composites.

For Macêdo et al. (2011) plant species with a slow release of extractives in the presence of water improves compatibility. According to Boadu et al. (2018), along with sugars and starches, tannins may also inhibit the cement glue. Based on the studies of Marques et al. (2016) it was concluded that the main physical variables that influence the response of greater or lesser compatibility of fiber-cement mixtures are: specific mass and degree of fiber swelling. Different types of lignocellulosic fibers absorb different amounts of water (FOELKEL, 2005) such that a variable amount of free water may be available to the cement, and thus influence the greatest temperature $\left(T_{\max }\right)$. According to Simatupang (1979) the amount of water ideal for the manufacture of cement-wood panels is inversely proportional to the density of the wood particles.

Barbosa (2011) studied several buriti fiber diameter ranges $(0.10$ to $0.80 \mathrm{~mm})$ and found that the apparent density of these lignocellulosic fibers increases as a function of their smaller diameters. Result also found by (GARCIA et al., 2013). The variation of the apparent density is directly related to the size of the particle that can influence the compatibility of the vegetal fibers (MUELLER et al., 2003). The absorption of water by the lignocellulosic fiber or its degree of swelling is a property directly linked to the chemical reactions between the constituents of the composite. According to Pomarico (2013) water and dissolved salts, mainly calcium carbonate, are absorbed by the fiber causing swelling, which occurs mainly in the hemicellulose due to its amorphous structure.

The bonds of metal cations and hydroxyl groups and certain wood substances, such as extractives, simple sugars, and hemicellulose, begin to form soluble and insoluble complexes that are diffused at the cement-wood interface. These physical and chemical characteristics of the plant fibers directly affect the composites produced with this material. In face of the study and analysis of physical and chemical variables (FERRARA et al., 2017), two adjustments were made in the compatibility of fibers with Portland cement without washing treatment. The first one takes into account physical and chemical variables, and the second, a simplified model, which takes into account physical and chemical variables obtained through simpler methodologies, achievable in laboratories with little technical equipment. 


\section{The $\mathrm{C}_{\mathrm{pc}}$ Compatibility Equation}

The CX compatibility model and the others reported in the literature need variables that are derived from the hydration process of the cementitious composite. This process of hydration occurs with the release of heat, as it is an exothermic chemical reaction, so it is possible to measure parameters such as greatest temperature of hydration and time to reach this maximum temperature. This information together with other such as the mass of materials, type of materials, specific heat, calorimeter properties and performing some calculations, it is possible to get information about the maximum heat generated and the rate of that heat. The determination of the hydration temperature of a cementitious composite requires equipment to use temperature sensors associated with an adiabatic calorimeter, not found in conventional laboratories.

Considering the limitations of the use of specific equipment for the study and determination of hydration temperature, a method of calculating compatibility is proposed. This method takes into account physicochemical parameters of the lignocellulosic fibers that influence the hydration process of the mixtures, but does not need the development of the hydration curve. The proposed $C_{\mathrm{PC}}$ model is a tool that uses lignocellulosic fiber characterization variables, which are obtained only once and are relatively easy to calculate. To obtain this model, physical and chemical variables such as soluble sugars (SS), degree of swelling (DS), relative specific mass (RSM), total soluble solids (TSS) and tannin content (TC) were taken into account shown in Table 2.

Table 2: Data of the physical-chemical variables used in the calculation of the linear regression of the $\mathrm{C}_{\mathrm{PC}}$ model.

\begin{tabular}{|l|l|l|l|l|l|l|l|}
\hline Lignocelullosic fibers & SM $\mathbf{~ ( g . c m ~}^{-\mathbf{3}}$ ) & RSM & DS & TSS (\%) & TC (\%) & SS (\%) & CX \\
\hline Cement & 3.04 & 1.00 & 0.00 & 0.00 & 0.00 & 0.00 & 1.00 \\
\hline \multirow{4}{*}{ Baroness } & 1.01 & 0.330 & 0.200 & 23.6 & 2.50 & 0.0900 & 0.780 \\
\cline { 2 - 8 } & 1.01 & 0.330 & 0.190 & 23.6 & 2.51 & 0.100 & 0.770 \\
\cline { 2 - 8 } & 1.00 & 0.330 & 0,210 & 23.5 & 2.49 & 0.080 & 0.780 \\
\hline Cocoa bark & 1.25 & 0.410 & 1.68 & 13.5 & 2.07 & 0.130 & 0.150 \\
\cline { 2 - 8 } & 1.25 & 0.410 & 1.72 & 13.7 & 2.08 & 0.140 & 0.140 \\
\cline { 2 - 8 } & 1,25 & 0.410 & 1.93 & 13.8 & 2.09 & 0.150 & 0.130 \\
\hline Coconut & 1.10 & 0.360 & 1.07 & 20.2 & 4.07 & 0.220 & 0.400 \\
\cline { 2 - 8 } & 1.25 & 0.410 & 1.05 & 20.1 & 4.05 & 0.200 & 0.410 \\
\cline { 2 - 8 } & 1.25 & 0.410 & 0.980 & 20.1 & 4.01 & 0.190 & 0.420 \\
\hline Eucalyptus bark & 1.25 & 0.410 & 1.10 & 22.1 & 4.89 & 0.450 & 0.490 \\
\cline { 2 - 8 } & 1.25 & 0.410 & 1.10 & 22.2 & 4.67 & 0.440 & 0.500 \\
\cline { 2 - 8 } & 1.25 & 0.410 & 1.09 & 22.1 & 4.48 & 0.430 & 0.510 \\
\hline
\end{tabular}

The RSM was obtained by the ratio between the specific mass of each fiber studied and the specific mass of the cement $\left(3.04 \mathrm{~g} \mathrm{~cm}^{-3}\right)$. The justification for the use of the relative value of the specific mass is related to the fact that all compatibility models proposed in the literature are also a relative factor. They are obtained by the relation between compatibility values of a mixture with lignocellulosic fiber with a mixture of pure cement. Thus, the $C X$ compatibility model itself is a relationship between variables that consider the lignocellulosic fibers over variables containing only cement. The RSM is a dimensionless term because it is a relationship between specific masses, as well as the DS, obtained by the ratio between the water mass absorbed by the fiber $(\mathrm{g})$ and dry fiber mass $(\mathrm{g})$.With a determination coefficient $\mathrm{R}^{2}$ of $99.64 \%$, the physicochemical compatibility model $C_{P C}$ describes the relationship between the $\mathrm{CX}$ compatibility index and five independent variables (SS, DS, RSM, TSS, and TC). The adjusted model equation ( $\left.C_{P C}\right)$ is: 


$$
C_{P C}=\alpha+\beta \cdot S S+\gamma \cdot D S+\varphi \cdot R S M+\mu \cdot T S S+\delta \cdot T C
$$

At where:

$\mathrm{C}_{\mathrm{PC}}$ - Physical-Chemical Compatibility; SS - Soluble sugars (\%); DS - Degree of swelling; $\mathrm{RSM}$ - Specific relative mass; TSS - Total soluble solids (\%); TC - Tannin content (\%).

The values of the constants $\alpha, \beta, \gamma, \phi, \mu$ and $\delta$, as well as the value of each error of the constants and their probability of significance, can be found in Table 3 . The constant $\alpha$ was not statistically significant at a level of confidence of $90 \%$, as well as the variable $\mu$, with values of probabilities higher than 0.10 . The other variables exerted a significant influence since the probability values of the independent variables were lower than 0.10 . Therefore, the terms $\beta, \gamma, \phi$ and $\delta$ of the equation are statistically significant at the confidence level of $90 \%$ or higher.

Table 3: Parameters obtained from the CPC compatibility model.

\begin{tabular}{|l|l|l|l|l|l|l|}
\hline & $\alpha$ & $\beta$ & $\gamma$ & $\boldsymbol{\phi}$ & $\boldsymbol{\mu}$ & $\boldsymbol{\delta}$ \\
\hline Constant & 0,1230 & 0.3891 & -0.3242 & 0.8744 & 0.0245 & -0.0732 \\
\hline Error & 0,4347 & 0.1674 & 0.0652 & 0.4348 & 0.0137 & 0.0182 \\
\hline Probability (P-value) & 0,7853 & 0.0531 & 0.0016 & 0.0842 & 0.1174 & 0.0050 \\
\hline
\end{tabular}

The model proposed by $\mathrm{C}_{\mathrm{PC}} \mathrm{Eq} .(8)$ is presented as an alternative for the evaluation and prior selection of lignocellulosic fibers for their use in cementitious matrixes, indicating the potentiality of application of these materials without the necessity of performing hydration curves tests. From a previous characterization of the physicochemical properties of the fibers and using the proposed $C_{P C}$ model, it is possible to obtain a prediction of the compatibility, which does not demand the preparation of the hydration curve of the composites produced with lignocellulosic fibers, similar to the response given by model of CX literature calculation.

\section{Modeling of the Simplified Compatibility Equation $\widetilde{\mathrm{CPC}}$}

From the results obtained of the significance of the coefficients of the variables of the $C_{P c}$ model, the simplified compatibility model was developed. $\left(\widetilde{C_{P C}}\right)$. This model is a tool to predict the compatibility with a reduced number of variables, which makes it even easier to apply. Variables such as specific mass, degree of swelling and total soluble solids are more easily found because they are simple characterization parameters and because they need less experimental capacity. The variables that make up the simplified model are relative specific mass (RSM), degree of swelling (DS) and total soluble solids (TSS), visualized in Table 4.

Table 4: Data of the physical-chemical variables used in the calculation of the multiple linear regression for the simplified model $\widetilde{C_{P C}}$

\begin{tabular}{|l|l|l|l|l|l|}
\hline Lignocelullosic Fibers & SM $\mathbf{~ g . c m}^{-3}$ ) & RSM & DS & TSS (\%) & CX \\
\hline Cimento & 3.04 & 1.00 & 0.00 & 0.00 & 1.00 \\
\hline \multirow{4}{*}{ Baroness } & 1.01 & 0.330 & 0.200 & 23.6 & 0.780 \\
\cline { 2 - 6 } & 1.01 & 0.330 & 0.190 & 23.6 & 0.770 \\
\cline { 2 - 6 } & 1.00 & 0.330 & 0.210 & 23.5 & 0.780 \\
\hline \multirow{4}{*}{ Cocoa bark } & 1.25 & 0.410 & 1.68 & 13.45 & 0.150 \\
\cline { 2 - 6 } & 1.25 & 0.410 & 1.72 & 13.7 & 0.140 \\
\cline { 2 - 6 } & 1.25 & 0.410 & 1.93 & 13.8 & 0.130 \\
\hline
\end{tabular}




\begin{tabular}{|l|l|l|l|l|l|}
\hline Coconut & 1.10 & 0.360 & 1.07 & 20.2 \\
\cline { 2 - 6 } & 1.25 & 0.410 & 1.05 & 20.1 \\
\cline { 2 - 6 } & 1.25 & 0.410 & 0.980 & 20.1 \\
\hline Eucalyptus bark & 1.25 & 0.410 & 1.10 & 0.410 \\
\cline { 2 - 5 } & 1.25 & 0.410 & 1.10 & 22.6 & 22.2 \\
\cline { 2 - 5 }
\end{tabular}

A multiple regression analysis, with a coefficient of determination $\mathrm{R}^{2}=98.28 \%$ was used to describe the relationship between the CX compatibility index and three independent physicochemical variables (DS, RSM, and TSS). The simplified model equation $\widetilde{C_{P C}}$ is:

$$
\widetilde{C_{P C}}=\alpha+\gamma \cdot D S+\varphi \cdot R S M+\mu \cdot T S S
$$

At where:

$C_{P C}$ - Physical-chemical compatibility; $\mathrm{RSM}$ - Specific relative mass; DS - Degree of swelling; TSS - Total soluble solids (\%).

The values of the constants, $\alpha, \gamma, \phi$ and $\mu$, as well as the error value of each constant and its probability of significance, can be found in Table 5 . It is noted that the only term that did not present a confidence level of $90 \%$ was the constant $\alpha$. The other variables exerted a significant influence, since the probability values of the independent variables were less than 0.10 . The coefficient of the variable Degree of swelling is preceded by a negative sign which indicates that the degree of swelling decreases would reduce the chemical-physical compatibility. Therefore, all other terms of the equation are statistically significant at the $90 \%$ confidence level or higher.

Table 5: Parameters obtained from the simplified compatibility model $\widetilde{C_{F Q}}$ for $90 \%$ confidence.

\begin{tabular}{|l|l|l|l|l|}
\hline & $\alpha$ & $\gamma$ & $\boldsymbol{\phi}$ & $\boldsymbol{\mu}$ \\
\hline Constant & 0.327 & -0.357 & 0.669 & 0.0121 \\
\hline Error & 0.197 & 0.0275 & 0.202 & 0.00500 \\
\hline Probability (P-value) & 0.130 & 0.000 & 0.00900 & 0.0390 \\
\hline
\end{tabular}

The model $\widetilde{C_{P C}}$ of Eq. (9) presents a proposal for a measure of compatibility that corresponds to the compatibility model $\mathrm{CX}$ of the literature, with a high coefficient of adjustment, taking into account the physical and chemical variables of simple and rapid attainment. The Table 6 presents the mean values of compatibility of the models obtained by the multiple linear regression of seven lignocellulosic fibers without wash: baronesa, cocoa, coconut, eucalyptus, banana peel, banana stem and piaçava.

Table 6 shows that the proposed compatibility model corresponds most to the CX compatibility model. In addition to the high value of the determination coefficient $R^{2}(99.6 \%)$. This model correlates physical and chemical variables that influence directly on the hydration mechanisms of the cementitious composites made with lignocellulosic fibers.

The influence of physical variables in the measure of greater or lesser compatibility has already been studied by Marques et al. (2016), concluding that these variables cannot be discarded. The methods of calculation of compatibility to date, do not consider in their models the physical and chemical variables studied, only parameters (mass and specific heat). These variables correlate with the thermal parameters of the exothermic hydration reactions, since the main criterion of compatibility of the measurement test is the 
curved hydration of the composite. Therefore, the physicochemical compatibility model $\mathrm{C}_{\mathrm{PC}}$ that consider both physical and chemical parameters was the one that most reflected the literature model, correlating in about $100 \%$ with the CX model.

Table 6: Mean values of compatibility obtained by the proposed formulas.

\begin{tabular}{|c|c|c|c|c|c|c|c|c|c|}
\hline Type os lignocelullosic fibers & $\begin{array}{l}\text { SM } \\
\left(\mathrm{g} \cdot \mathrm{cm}^{-3}\right)\end{array}$ & RSM & DS & $\begin{array}{l}\text { TSS } \\
\text { (\%) }\end{array}$ & $\begin{array}{l}\text { TC } \\
\text { (\%) }\end{array}$ & $\begin{array}{l}\text { SS } \\
(\%)\end{array}$ & CX & $\mathrm{CPC}_{\mathrm{PC}}$ & $\widetilde{\mathrm{CPC}_{\mathrm{PC}}}$ \\
\hline Portland Cement & 3.040 & 1.000 & 0.000 & 0.000 & 0.000 & 0.000 & 1.000 & 1.000 & 1.000 \\
\hline Baroness & 1.007 & 0.3310 & 0.2000 & 23.56 & 2.500 & 0.09000 & 0.7800 & 0.7800 & 0.7600 \\
\hline Cocoa bark & 1.250 & 0.4110 & 1.777 & 13.64 & 2.080 & 0.1400 & 0.1400 & 0.1400 & 0.1300 \\
\hline Coconut & 1.200 & 0.3950 & 1.033 & 20.11 & 4.043 & 0.2030 & 0.4100 & 0.4100 & 0.4400 \\
\hline Eucalyptus bark & 1.250 & 0.4110 & 1.097 & 22.28 & 4.680 & 0.4400 & 0.5000 & 0.5000 & 0.4800 \\
\hline Banana peel & 1.250 & 0.4110 & 0.6850 & 25.93 & 3.763 & 0.1500 & 0.6700 & 0.6800 & 0.6700 \\
\hline Banana stem & 1.667 & 0.5480 & 0.6740 & 32.25 & 5.327 & 0.1320 & 0.8500 & 0.8300 & 0.8400 \\
\hline Piaçava * & 1.250 & 0.4110 & 0.1440 & 3.417 & 0.2330 & 0.2650 & 0.6300 & 0.6100 & 0.5900 \\
\hline
\end{tabular}

${ }^{*}$ Attalea funifera

Another proposal presented was the simplified compatibility model $\widetilde{C_{P C}}$ which showed a high correlation of the values of compatibility with all the fibers tested, offering an alternative of previous choice of loignocellulosic fibers, with variables that are obtained through fast test methodologies and simple. In this way, internal validation tests of these two models $\left(C_{P C}\right.$ and $\widetilde{C_{P C}}$ were performed to compare the means of the compatibility values obtained by the $\mathrm{CX}$ model and the proposed models.

\section{Internal Validation Test of the $\mathrm{C}_{\mathrm{pc}}$ and $\widetilde{\mathrm{CPC}_{\mathrm{PC}}}$ Models}

The internal validation test of compatibility models $\left(C_{P C}\right.$ e $\left.\widetilde{C_{P C}}\right)$ were made in the four studied lignocellulosic fibers, baronesa, cocoa, coconut and eucalyptus, and in three other fibers (banana peel, banana stem and piaçava) all without washing. Were apply the t-Student test with three replicates for each fiber. Student's t-test was applied to verify if the compatibility models ( $C_{P C}$ and $\widetilde{C_{P C}}$ are statistically comparable to the value obtained by the CX. Table 6 shows the effects of the parameters for the two models, the probability ( $p$-value) and the experimental $t$ (texp). Once the calculated probability is equal to or greater than 0.05 , we cannot reject the null hypothesis with a $95 \%$ confidence level.

The comparison test between the means of the proposed physico-chemical compatibility $\left(C_{P C}\right)$ model and the CX model showed that there are no statistically significant differences between the compatibility values for all the tested lignocellulosic fibers. When comparing with the simplified model $\widetilde{C_{P C}}$ the eucalyptus fiber did not show the same correlation. The results of the compatibility averages for this fiber were significantly different, with error probability lower than 0.05 . Although it is out of the range, to consider the null hypothesis as accepted, the probability value is near the limit, which indicates the possibility of this parameter being used in general for other fibers as a first approximation.

The proposed compatibility model $C_{P C}$ is another tool that enables the qualification and earlier choice of compatibility between lignocellulosic fiber residues and Portland cement matrices. It does not substitute or exclude the more detailed analysis of the behavior of these fibers in cement matrices with the measurement of the heat of hydration, but it is placed as a predictive alternative of the earlier choice of 
lignocellulosic fibers with focus on cementitious matrices.

Table 7: Parameters obtained from the student $t$ test of the validation of the models $C_{P C}$ and $\widetilde{C_{P C}}$

\begin{tabular}{|l|l|l|l|l|}
\hline & $C_{P C}$ & \multicolumn{2}{c|}{} \\
\hline Fiber & Probability & $t_{\text {exp }}$ & Probability & $t_{\text {exp }}$ \\
\hline Baroness & 0.643 & 0.500 & 0.0670 & -2.50 \\
\hline Cocoa bark & 0.889 & 0.150 & 0.670 & -0.460 \\
\hline Coconut & 1.00 & 0.000 & 0.0530 & 2.47 \\
\hline Eucalyptus bark & 1.00 & 0.000 & $0.0450^{*}$ & $-2.70^{*}$ \\
\hline Banana peel & 0.720 & -0.380 & 0.725 & -0.380 \\
\hline Banana stem & 0.696 & 0.420 & 1.00 & 0.00 \\
\hline Piaçava & 0.251 & -1.34 & 0.105 & -2.08 \\
\hline
\end{tabular}

*: The null hypothesis is not accepted

Null hypothesis: $\mathrm{CX}$ mean equal to the mean of the model $\left(C_{P C}\right.$ e $\widetilde{C_{P C}}$ )

\section{Potentiality of use of Lignocellulosic Fibers based on Compatibility Calculation $\widetilde{\mathrm{PC}_{\mathrm{PC}}}$}

The potential use of lignocellulosic fibers of different origins and species was analyzed based on the results of the simplified compatibility model $\widetilde{C_{P C}}$, applying data of the physicochemical variables available in the literature. The possibility of earlier classification of the potential use of a lignocellulosic fiber in cementitious matrixes without the need to make composites with these fibers and to measure the hydration curve, using only physical and chemical characterization variables of simple was one of the motivators of the work.

Thus, a literature search was carried out to extract the independent variables that make up the simplified model, which are: specific mass, swelling degree, and total soluble solids, of the main fibers used in cementitious matrixes (Table 8). In most jobs, it was not possible to get the three variables together. For these cases, the variables that were not found were replaced with data of other authors, observing the similarity of the specific conditions of obtaining these parameters in the different works. Because it does not have a single source, the compatibility values are only estimates. Monteiro et al. (2011) carried out an extensive study on the tensile properties of different species of lignocellulosic fibers (cotton, rami, jute, sisal and flax) showing the greatest and least values of specific mass for each fiber. For the purposes of calculating compatibility, the average value of this property was considered.

The swelling degree data for the flax, jute, rami, sisal and cotton fibers presented by Nadolny (2013) were taken from The Food and Agriculture Organization of the United Nations, which also shows average values of mass for these fibers. For the purposes of calculating compatibility $\widetilde{C_{P C}}$ it was decided to consider the values presented by Monteiro et al. (2011) due the national origin of the fibers. The degree of swelling for the curauá fiber, bromeliad characteristic of the Paraense Amazon belonging to the pineapple family (Ananas comosus) was taken from the work of Rosa et al. (2012). The authors calculated the water absorption index using the same mathematical formula that was used in the present research to calculate the degree of swelling, however, they worked with long fibers, $7 \mathrm{~cm}$.

The total soluble solids contents presented by Satyanarayanaa et al. (2007) are of curauá and coconut fibers produced in Brazil, as well as those presented by Pires (2009) with data for sisal fiber, whose solids extraction method was obtained with hot water, similar to the present research. In Figure 1 the compatibility 
behavior of the model $\widetilde{C_{P C}}$ of the fibers presented in Table 7 is shown. The red line was used to separate fibers with more than $50 \%$ compatibility and below this value, therefore with high compatibility and low compatibility.

Table 8: Physical-chemical parameters reported for different fibers found in the literature and results obtained from $\widetilde{C_{P C}}$

\begin{tabular}{|c|c|c|c|c|c|c|c|}
\hline Sequence & Researcher & Lignocelullosic Fibers & $\begin{array}{l}\mathrm{SM} \\
\left(\mathrm{g} / \mathrm{cm}^{3}\right)\end{array}$ & RSM & DS & $\begin{array}{l}\text { TSS } \\
\text { (\%) }\end{array}$ & $\widetilde{C_{P C}}$ \\
\hline \multirow[t]{8}{*}{1} & \multirow[t]{8}{*}{ Marques (2016) } & Cement CPV-ARI & 3.04 & 1.00 & 0.00 & 0.00 & 1.00 \\
\hline & & Baroness & 1.01 & 0.330 & 0.200 & 23.6 & 0.760 \\
\hline & & Cocoa bark & 1.25 & 0.410 & 1.78 & 13.5 & 0.130 \\
\hline & & Coconut & 1.20 & 0.390 & 1.01 & 20.2 & 0.470 \\
\hline & & Eucalyptus bark & 1.25 & 0.410 & 1.10 & 22.5 & 0.480 \\
\hline & & Banana peel & 1.58 & 0.520 & 0.690 & 32.3 & 0.820 \\
\hline & & Banana stem & 1.17 & 0.380 & 0.710 & 25.9 & 0.640 \\
\hline & & Piaçava & 1.25 & 0.410 & 0.150 & 3.42 & 0.590 \\
\hline \multirow[t]{2}{*}{2} & \multirow[t]{2}{*}{ Marinelli et al. (2008) } & Curauá & 1.40 & 0.460 & $0.700 * * *$ & $2.65^{* * * *}$ & 0.420 \\
\hline & & Sisal & 1.50 & 0.490 & $0.110^{* *}$ & $17.0^{* * * * *}$ & 0.820 \\
\hline 3 & Bicalti (2015) & Curauá & 0.67 & 0.220 & 0.130 & 4.02 & 0.480 \\
\hline 4 & Savastano Jr. et al. (1994) & Sisal & 1.37 & 0.450 & 1.10 & $17.0 * * * * *$ & 0.440 \\
\hline 5 & Leão (2008) & Licuri & 0.542 & 0.180 & 1.10 & 17.6 & 0.260 \\
\hline 6 & Young (1994) & Sisal & $1.38^{*}$ & 0.450 & $0.110 * *$ & 16.2 & 0.790 \\
\hline 7 & Guimarães Jr. et al. (2013) & Bambu & 1.43 & 0.470 & 0.420 & 7.50 & 0.580 \\
\hline \multirow[t]{5}{*}{8} & \multirow[t]{5}{*}{ Bledzki et al. (1999) } & Cotton & $1.55^{*}$ & 0.510 & $0.170 * *$ & 1.00 & 0.620 \\
\hline & & Juta & $1.37^{*}$ & 0.450 & $0.120 * *$ & 1.10 & 0.600 \\
\hline & & Flax & $1.40^{*}$ & 0.460 & $0.070 * *$ & 3.90 & 0.660 \\
\hline & & Rami & $1.50^{*}$ & 0.490 & $0.150 * *$ & 5.50 & 0.670 \\
\hline & & Sisal & $1.38^{*}$ & 0.450 & $0.110^{* *}$ & 1.20 & 0.610 \\
\hline
\end{tabular}

*: Monteiro et al. (2011); ${ }^{* *}$ : Nadolny (2013); ${ }^{* *}$ : Rosa et al. (2012); ${ }^{* * *}$ : Satyanarayanaa et al. (2007); ${ }^{* * * * *}$ : Pires (2009).

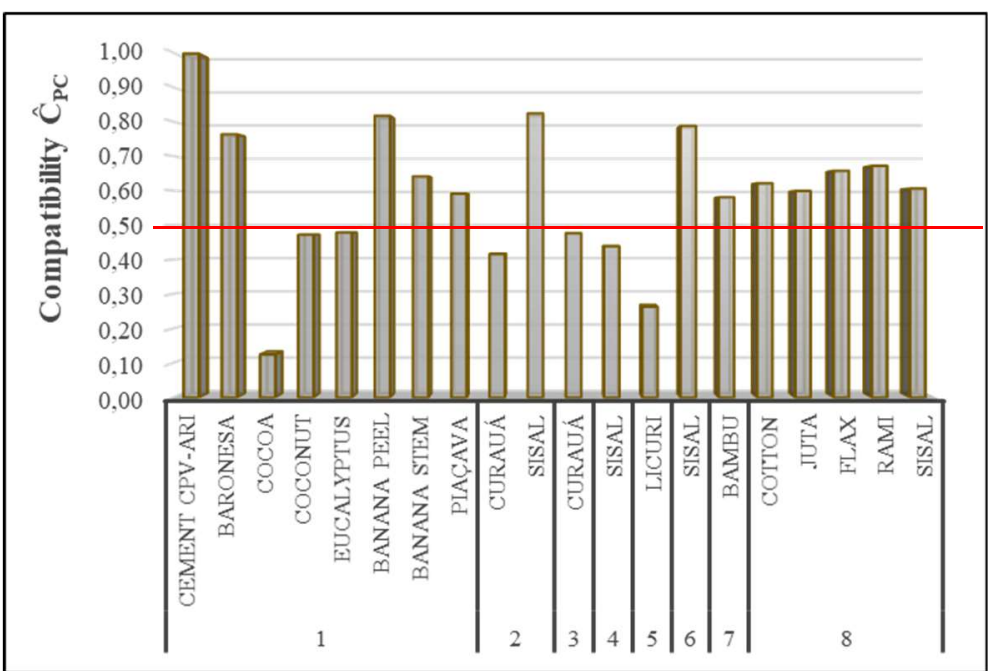

Fig. 1: Compatibility $\widetilde{C_{P C}}$ of vegetable fibers from the literature.

The compatibility classification, that is, whether the lignocellulosic fiber is adequate or inadequate for use in cementitious matrices is proposed by the researchers according to their own compatibility value. For Vilela et al. (1968) the aptitude (A) is classified as poor if $A$ is less than $50 \%$, and good if $A$ is greater than $80 \%$. For Hachmi et al. (1990) the CA compatibility is considered to be incompatible if the value is less than $28 \%$ and compatible if it exceeds $68 \%$.

Following the classification proposed in the paper, of the 19 fibers analyzed, 12 are considered compatible and 7 are incompatible. If the fibers are now classified according to the Hachmi et al. (1990) 
classification parameters, 4 will be considered compatible and 2 will be incompatible, the others will be moderately compatible. It is also noted variability in the compatibility value of fibers of the same forest species, as in the case of sisal fiber. This variability may be due to physicochemical properties of the fiber and dependent on the parameters of its preparation, such as grain size and fiber grinding.

\section{Compatibility variability in a single fiber species}

Mohanty et al. (2000) report that the properties of fibers of the same species can vary considerably. This depends on whether the lignocelullosic fiber comes from parts such as stems or leaves, the quality of plant site, climatic and planting conditions and age of the plant, unlike synthetic fibers (glass, carbon, aramid) that can be produced more with more defined properties. Therefore, the chemical composition of the lignocellulosic fibers is sensitive to several factors, resulting in a high variety also of its mechanical properties.

In this sense, taking as an example the coconut fiber, due to the greater availability of data in the literature, an analysis was made to compare the $\widetilde{C_{P C}}$ obtained with coconut fibers from different origins, visualized in Table 9, to verify if there is occurrence of variability in the value of compatibility for fibers of the same forest species.

Table 9: Variables of the compatibility equation $\widetilde{C_{P C}}$ for the coconut fiber of different researchers.

\begin{tabular}{|c|c|c|c|c|c|c|c|}
\hline Sequence & Researcher & Types of Fibers & $\begin{array}{l}\mathrm{SM} \\
\left(\mathrm{g} / \mathrm{cm}^{3}\right)\end{array}$ & RSM & DS & $\begin{array}{l}\text { TSS } \\
\text { (\%) }\end{array}$ & $\widetilde{C_{P C}}$ \\
\hline \multirow[t]{2}{*}{1} & \multirow[t]{2}{*}{ Marques (2016) } & Cement CPV-ARI & 3.04 & 1.00 & 0.00 & 0.00 & 1.00 \\
\hline & & Coconut & 1.20 & 0.390 & 1.01 & 20.2 & 0.470 \\
\hline 2 & Luzardo et al. (2015) & Coconut & $1.33^{*}$ & 0.440 & 1.01 & 18.3 & 0.480 \\
\hline 3 & Marinelli et al. (2008) & Coconut & 1.20 & 0.390 & $0.00 * *$ & $3.50 * * * *$ & 0.600 \\
\hline 4 & Savastano Jr. et al. (1994) & Coconut & 1.18 & 0.390 & 0.940 & $3.50 * * * *$ & 0.290 \\
\hline 5 & Brígida et al. (2003) & Coconut & $1.33^{*}$ & 0.440 & $0.100 * *$ & 1.14 & 0.600 \\
\hline
\end{tabular}

*: Monteiro et al. (2011); **: Nadolny (2013); ${ }^{* * *}$ : Rosa et al. (2012); ${ }^{* * * *}$ : Satyanarayanaa et al. (2007); *****: Pires (2009).

Following the same classification of compatibility, above 50\% compatible and below, incompatible, three coconut fibers would be classified as not suitable for incorporation in cementitious matrices and two as fit or compatible (Figure 2). The compatibility value is above $50 \%$ for the data presented in sequences 3 and 5 , and below $50 \%$ in the sequence 1, 2 and 4 , which allows concluding that a previous evaluation of the potentiality of use of residues of lignocellulosic fibers by the high variability characteristics that these fibers present, whether due to the grinding process, granulometry, or even to the vegetal characteristics of the fiber itself. The same species of vegetal fiber can be considered suitable or not, for use in cementitious matrices.

The high variability in the physical and chemical properties of the fibers is an important factor when determining compatibility. Even fibers of the same plant species show a high oscillation in the parameters of measurement due to climatic conditions, cutting season, grain size, origin, age of plants and extraction methods that can change the composition of the fibers (KABIR et al., 2012), which demands, even more, the need for earlier classification of these lignocellulosic fibers.

It is expected that the possibility of earlier classifying the lignocellulosic fibers in compatible or not 
compatible in mixtures of Portland cement, through the $\mathrm{C}_{\mathrm{PC}}$ compatibility factor, can bring results in the short, medium and long term, expanding the studies in this area. This result offers alternatives to the use of wood, its residues and other lignocellulosic fibers, as source of raw material in cementitious matrixes.

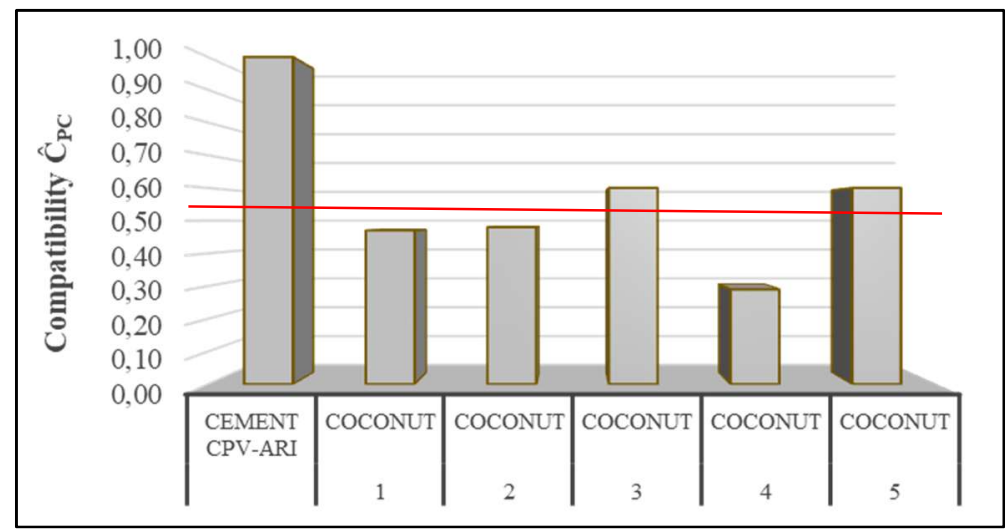

Fig. 2: Compatibility $\widetilde{C_{P C}}$ of coconut fibers from the literature.

\section{CONCLUSIONS}

The physicochemical compatibility model $\mathrm{C}_{\mathrm{PC}}$, developed in the present work, is presented as a reliable alternative in the choice and earlier qualification of lignocellulosic fibers, as it correlates in almost $100 \%$ with the CX compatibility index of the literature; The simplified physical-chemical compatibility model $\widetilde{C_{P C}}$ is presented as a further developed alternative for the previous choice of these fibers, considering variables that are obtained through simple and rapid test methodologies such as: specific mass, degree of swelling and total soluble solids; The use of the $C_{P C}$ and models $\widetilde{C_{P C}}$ represent in the technical aspect a new method, of easy handling and quick response, that can be explored to earlier select vegetal fibers; In the social aspect, it represents the possibility of generating employment in terms of the processing of different plant residues and the manufacture of artifacts produced with these residues, and the possibility of being able to offer construction materials that are cheaper and locally accessible, since it would work with residues of products natives in each region; In the environmental aspect, it represents the sustainable use of wastes that are improperly discarded in the environment, reducing the proliferation of vectors associated with diseases, from being an environmental liability, to be processed as raw material for civil construction purposes, generate profits for the private sector and reduce environmental problems of interest to society.

ACKNOWLEDGEMENTS: The authors thank FAPESB - Foundation for Research Support of the State of Bahia for granting the doctoral scholarship.

\section{REFERENCES}

ALBERTO, M. M.; MOUGEL, E.; ZOULALIAN, A.. Compatibility of some tropical hardwoods species with Portland cement using isothermal calorimetry. Forest Products Journal, v.50, n.9, p.83-88, 2000

ASASUTJARIT, C; HIRUNLABH, J.; KHEDARI, J.; CHAROENVAI, S.; ZEGHMATI, B.; SHIN, U. C.. Development of coconut coir- based lightweight cement board. Construction and Building Materials, v.21, n.2, p.277-288, 2007. DOI: https://doi.org/10.1016/j.conbuildmat.2005.08.028

BICALTI, G. K.. Produção de painéis de cimento portland reforçados com fibra de curauá (Ananas erectifolius). Dissertação (Mestrado em Engenharia Civil) - Universidade 
Federal do Paraná, Curitiba, 2015.

BIN, N. A.; ZHIQIANG, W.; HAIQIN, W.; XIAONING, L.. Woodcement compatibility review. Wood Research, v.5, n.59, p.813-826, 2014

BLEDZKI, A. K.; GASSAN, J.. Composites Reinforced with cellulose based fibers. Progress in Polymer Science, v.24, n.2, p.221-274, 1999. DOI: https://doi.org/10.1016/S0079$\underline{6700(98) 00018-5}$

BOADU, K. B.; ANTWI-BOASIAKO, C.; OFOSUHENE, L.. Solvent extraction of inhibitory substances from three hardwoods of different densities and their compatibility with cement in composite production. J Indian Acad Wood Sci, v.15, n.2 p.140-148, 2018. DOI: https://doi.org/10.1007/s13196-018$\underline{0219-0}$

BRÍGIDA, A. I. S.; ROSA, M. F.. Determinação do Teor de Taninos na Casca de Coco Verde (Cocos nucifera). Proc. Interamer. Soc. Trop. Hort., v.47, p.25-27, 2003.

CALADO, V.; BARRETO, D. W.; D'ALMEIDA, J. R. M.. The effect of a chemical treatment on the structure and morphology of coir fibers. Journal of Materials Science Letters, v.19, n.23, p.2151-2153, 2000. DOI: https://doi.org/10.1023/A:1026743314291

FAN, M.; NDIKONTAR, M. K.; ZHOU, X.; NGAMVENG, N. . Cement-bonded composites made from tropical woods: Compatibility of wood and cement. Construction and Building Materials, v.36, p.135-140, 2012. DOI: https://doi.org/10.1016/i.conbuildmat.2012.04.089

FERRARA, L.; FERREIRA, S. R.; KRELANI, V.; LIMA, P.; SILVA, F.; TOLEDO FILHO, R. D.. Cementitious Composites Reinforced with Natural Fibres. In: BARROS, J.; FERRARA, L.; MARTINELLI, E.. Recent Advances on Green Concrete for Structural Purposes. Research for Development. Springer, Cham., p.197-33, 2017. DOI: https://doi.org/10.1007/978-3319-56797-6 9

FERRAZ, J. M.; DELMENEZZI, C. H. S.; SOUZA, M. R.; OKINO, E. Y. A.; MARTIN, S. A.. Compatibility of Pretreated Coir Fibres (Cocos nucifera L.) with Portland Cement to Produce Mineral Composites. International Journal of Polymer Science, p.7, 2012. DOI: http://dx.doi.org/10.1155/2012/290571

FOELKEL, C.. Casca da árvore do eucalipto: Aspectos morfológicos, fisiológicos, florestais, ecológicos e industriais, visando a produção de celulose e papel. Eucalyptus Online Book \& Newsletter, 2005

GARCIA, D. P.; CARASCHI, J. C.; VENTORIM, G.. Caracterização energética de pellets de madeira. In: CONGRESSO INTERNACIONAL DE BIOENERGIA, 7. Anais. São Paulo: 2013, p.6.

GUIMARÃES JR., M.; NOVACK, K. M.; BOTARO, V. R.; PROTÁSIO, T. P.; COUTO, A. M.. Caracterização físico-química de fibra e polpas de Bambusa vulgaris Schrad para utilização em compósitos poliméricos. Revista Latinoamericana de Metalurgia Y Materiales, v.33, n.1, p.33-42, 2013.

HACHMI, M.; MOSLEMI, A. A.; CAMPBELL, A. G.. A new technique to classify the compatibility of wood with cement.
Wood Science and Technology, v.24, n.4, p.345-354, 1990. DOI: https://doi.org/10.1007/BF00227055

HERRERA, R. E.; CLOUTIER, A.. Compatibility of four eastern canadian woods with gypsum and gypsum-cement binders by isothermal calorimetry. Maderas, Ciência e Tecnologia, v.10, n.3, p.275-288, 2008.

DOI:http://dx.doi.org/10.4067/S0718-221X2008000300009

HOFSTRAND, A. D.; MOSLEMI, A. A.; GARCIA, J. F.. Curing characteristics of wood particles from nine northern Rocky Mountain species mixed with Portland cement. Forest Products Journal, v.34, n.2, p.57-61, 1984.

JORGE, F. C.; PEREIRA, C.; FERREIRA, J. M. F.. Wood-cement composites: a review. Holz Roh Werkst, v.62, p.370-377, 2004. DOI: https://doi.org/10.1007/s00107-004-0501-2

KABIR, M. M.; LAU, H. W. K. T.; CARDONA, F.. Chemical treatments on plant: based natural fibre reinforced polymer composites. Elsevier Composites: Part B, v.43, p.2883-2892, 2012. DOI:

https://doi.org/10.1016/j.compositesb.2012.04.053

KAREDE, S. R.; IRLE, M.; MAHER, K.. Assesment of woodcement compatibility: A new approach. Holzforshung, v.57, n.6, p.672-680, 2003. DOI:

https://doi.org/10.1515/HF.2003.101

LEÃO, M. A.. Fibras de licuri: Um reforço alternative de compósitos poliméricos. Dissertação (Mestrado em Engenharia Mecânica) - Universidade Federal do Rio Grande do Norte, Natal, 2008

LIMA, A. J. M.; IWAKIRI, S.; LOMELÍ-RAMÍREZ, M. G.. Study of the Interaction of Portland Cement and Pinus Wood for Composites using Bragg Sensors in Optical Fibers. Cement \& wood sensing, BioResources, v.10, n.4, p.6690-6704, 2015.

MACÊDO, A. N.; LIMA, A. M.; FONSECA, F. O.; LAVÔR, B. V. A.. Análise estatística do comportamento mecânico à compressão do compósito cimento-madeira. Revista Matéria, v.16, n.2, p.658-667, 2011. DOI: http://dx.doi.org/10.1590/S1517-70762011000200002

MARINELLI, A. L.; MONTEIRO, M. R.; AMBRÓSIO J. D.; BRANCIFORTI, M. C.; KOBAYASHI, M.; NOBRE, A. D.. Desenvolvimento de Compósitos Poliméricos com Fibras Vegetais Naturais da Biodiversidade: Uma contribuição para a sustentabilidade Amazônica. Polímeros, Ciência e Tecnologia, v.18, n.2, p.92-99, 2008. DOI: http://dx.doi.org/10.1590/S0104-14282008000200005

MARQUES, M. L.; LUZARDO, F. H. M.; GARCIA, F. C.; GONZÁLEZ, L. N.; SILVIA, E. J.; LIMA, W. G.. Compatibility of vegetable fibers with Portland cement and its relationship with the physical properties. Revista Brasileira de Engenharia Agrícola e Ambiental, v.20, n.5, p.466-472, 2016. DOI: http://dx.doi.org/10.1590/18071929/agriambi.v20n5p466-472

MOHANTY, A. K.; MISRA, M.; HINRICHSEN, G.. Biofibres, biodegradable polymers and biocomposites: An overview. Macromolecular Materials and Engineering, v.276-277, n.1, p.1-24, 2000. DOI: https://doi.org/10.1002/(SICI)14392054(20000301)276:1<1::AID-MAME1>3.0.CO;2-W 
MONTEIRO, S. N.; PERISSÉ, F. D. L.; COSTA, L. L.; BEVITORI, A. B.; SILVA, I. A. S.; BARBOSA, A. P.. Natural Lignocellulosic Fibers as engineering materials: an overview. The minerals, metals \& materials Society and ASM International, v.42A, p.2923-2974, 2011. DOI: https://doi.org/10.1007/s11661$\underline{011-0789-6}$

MUELLER, D. H.; KROBJILOWSKI, A.. New discovery in the properties of composites reinforced with natural fibers. Journal of Industrial Textiles, v.33, n.2, p.100-130, 2003. DOI: https://doi.org/10.1177/152808303039248

NADOLNY, P. R.. Utilização de reforço lignocelulósico em polietileno de alta densidade. Dissertação (Mestrado em Engenharia e Ciência dos Materiais) - Universidade Federal do Paraná, Curitiba, 2013.

OLORUNNISOLA, A. O.. Effects of pre-treatment of rattan (Laccosperma secundiflorum) on the hydration of Portland cement and the development of a new compatibility index. Cement \& Concrete Composites, n.30, p.37-43, 2008. DOI: https://doi.org/10.1016/i.cemconcomp.2007.08.002

PACHECO-TORGAL, F.; JALALI, S.. Cementitious building materials reinforced with vegetable fibres: A review. Construction and Building Materials, v.25, p.575-581, 2011. DOI: https://doi.org/10.1016/j.conbuildmat.2010.07.024

PASCA, S. A.; HARTLEY, I. D.; REID, M. E.; THRING, R. W.. Evaluation of compatibility between beetle-killed lodgepole pine (pinus contorta var. Latifolia) wood with portland cement. Materials, v 3, p.5311-5319, 2010. DOI: http://doi.org/10.3390/ma3125311

PIRES, J. S. C.. Fibras Naturais: Características químicas e potenciais aplicações. Monografia (Graduação) Universidade Estadual Paulista, Botucatu, 2009.

POMARICO, F. A.. Potencial de utilização da madeira de Clones de Eucalipto na Produção de Painéis: Cimento. Dissertação (Mestrado em Engenharia Florestal) Universidade Federal de Lavras, Lavras, 2013.

RAMADEVI, P.; SAMPATHKUMAR, D.; SRINIVASA, C. V.; BENNEHALLI, B.. Effect of alkali treatment on water absorption of single cellulosic abaca fiber. BioResources, v.7, n.3, p.3515-3524, 2012.

RAMOS, L. P.. The chemistry involved in the steam treatment of lignocellulosic materials. Química Nova, v.26, n.6, p.863871, 2003. DOI: http://dx.doi.org/10.1590/S0100$\underline{40422003000600015}$

ROSA, C. C.; MOREIRA, D. D. C.; BICALTI, G. K.. Estudo das propriedades físicas da fibra de curauá. In: CONGRESSO BRASILEIRO DE EDUCAÇÃO EM ENGENHARIA, 40. Anais. Belém, 2012. p.8.

SANDERMAN, W.; KHOLER, R.. Studies on Mineral Bonded Wood Materials IV. A short test of the aptitudes of woods for cement bonded materials. Holzforshung, v.18, n.12, p.53-59, 1964

SATYANARAYANAA, K. G.; GUIMARÃES, J. L.; WYPYCHA, F. Studies on lignocellulosic fibers of Brazil. Part I: Source, production, morphology, properties and applications. Composites Part A: Applied Science and Manufacturing, v.38, n.7, p.1694-1709, 2007. DOI: https://doi.org/10.1016/j.compositesa.2007.02.006

SAVASTANO JR, H.; DANTAS, F. A. S.; AGOPYAN, V. Materiais reforçados com fibras: correlação entre a zona de transição fibra-matriz e as propriedades mecânicas. São Paulo: Pini, 1994.

SIMATUMPANMG, H.. The water requirement of manufactured cement-bonded particleboard. Holz RohWerkst, v.37, p.379-382, 1979.

VILELA, E.; DU PASQUIER, B.. Determinación del coeficiente de aptitud de un grupo de maderas para su posible aplicación en la fabricación de tableros de pajilla de madera. Revista Forestal Venezolana, v.11, n.16, p.75-84, 1968.

WEATHERWAX, R. C.; TARKOW, H.. Effect of wood on setting of Portland cement. Forest Products Journal, v.14, n.12, p.567-570, 1964.

YOUNG, R. A.. Fibers (Vegetable). Kirk-Otthmer encyclopedia of chemical Tecnology 4th. J. Wiley \& Sons, Inc., 1994.

A CBPC - Companhia Brasileira de Produção Científica (CNPJ: 11.221.422/0001-03) detém os direitos materiais desta publicação. Os direitos referem-se à publicação do trabalho em qualquer parte do mundo, incluindo os direitos às renovações, expansões e disseminações da contribuição, bem como outros direitos subsidiários. Todos os trabalhos publicados eletronicamente poderão posteriormente ser publicados em coletâneas impressas sob coordenação da Sustenere Publishing, da Companhia Brasileira de Produção Científica e seus parceiros autorizados. Os (as) autores (as) preservam os direitos autorais, mas não têm permissão pab coordenção da Sustenere Publishing, da Companhia Brasileira de Produção Cientifica e seus pã 